\title{
Adenomyoma of the lleum Leading to Intussusception
}

\author{
Makoto Takeda ${ }^{a}$ Tuyoshi Shoji ${ }^{b}$ Masanori Yamazaki ${ }^{b}$ \\ Yukihiro Higashi ${ }^{\mathrm{b}}$ Hirotoshi Maruo ${ }^{\mathrm{b}}$ \\ aDepartment of Surgery, Kikugawa General Hospital, Kikugawa, and

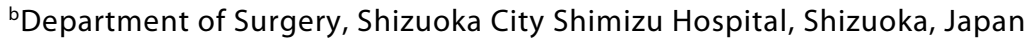

\section{Key Words}

Adenomyoma $\cdot$ Intussusception $\cdot$ Heterotopic pancreatic tissue

\begin{abstract}
Adenomyoma of the ileum is a rare condition. A 68-year-old Japanese man presented with nausea and distension of the abdomen. Enhanced computed tomography of his abdomen revealed wall thickening in the ileum and dilation of the proximal small intestine. Open laparotomy was performed to find the cause of the patient's small bowel obstruction, and a tumor was found in the ileum, which had resulted in intussusception. The tumor and $20 \mathrm{~cm}$ of the adjacent ileum were resected. The resected specimen displayed a macroscopic appearance suggestive of a submucosal tumor. Histopathological evaluation showed duct cell proliferation and bundles of smooth muscle cells from the mucosa to the serosa, leading to a diagnosis of adenomyoma. Immunohistochemical examination found that cytokeratin 7 and carbohydrate antigen 19-9 were expressed in the duct epithelia. We report a rare case of ileal adenomyoma leading to intussusception in an adult and present the immunohistochemical evaluation of the adenomyoma.
\end{abstract}

\section{Introduction}

Adenomyoma of the gastrointestinal tract is a rare benign tumor-like lesion which usually occurs in the pylorus of the stomach or duodenum. Its occurrence in the small intestine distal to the duodenum is very rare. Histologically, adenomyoma is characterized by glandular structures lined by a cuboidal to tall columnar epithelium surrounded by bundles of smooth muscle cells. Although this lesion originates from abnormal embryonic buds, which can differentiate into pancreatic or duodenal tissue, its pathogenesis has not been fully elucidated. It is generally considered to represent either myoepithelial hamartoma or a form of heterotopic pancreatic tissue [1]. 
Adenomyoma of the ileum causes intussusceptions in children more often than in adults. Generally, intussusceptions are uncommon in adults and account for $0.003-0.02 \%$ of all hospital admissions. Adult intussusceptions represent $5 \%$ of all intussusception cases and are rarely caused by idiopathic lesions $[2,3]$. Due to the high incidence of malignancy, surgical intervention is required for adult intussusceptions, although barium hydrostatic reduction is performed in children. However, the extent of bowel resection required and whether the intussuscepted bowel should be reduced are disputed. Thus, the optimal treatment strategy for adult intussusceptions remains controversial [4].

Herein, we report an adult case of adenomyoma of the ileum leading to intussusceptions as a rare condition. We also performed a review of the English language literature to find cases of adenomyoma of the ileum, and we discuss our findings regarding the diagnosis, optimal treatment, and clinical features of the disease. Moreover, the pathogenesis of adenomyoma of the ileum has not been fully elucidated. Therefore, an immunohistochemical investigation of the pathogenesis of ileal adenomyoma is presented.

\section{Case Report}

A 68-year-old Japanese man with a past medical history of impaired glucose regulation and developmental canal spinal stenosis presented with nausea and distension of the stomach, which had lasted for 1 day. He had experienced a few episodes of vomiting and had not undergone laparotomy.

The patient's physical status on admission was as follows: body temperature $36.7^{\circ} \mathrm{C}$, blood pressure $122 / 66 \mathrm{~mm} \mathrm{Hg}$, and pulse rate 75 beats/min. Physical examination indicated distension of the abdomen without tenderness, rebound tenderness, or muscular rigidity. His laboratory data on admission were as follows: white blood cell count 7,000/ $\mu \mathrm{l}$, red blood cell count $532 \times 10^{4} / \mu \mathrm{l}$, hemoglobin $16.1 \mathrm{~g} / \mathrm{dl}$, platelets $22.3 \times 10^{4} / \mu \mathrm{l}$, lactate dehydrogenase $279 \mathrm{IU} / \mathrm{l}$, blood urea nitrogen $39 \mathrm{mg} / \mathrm{dl}$, creatine $0.90 \mathrm{mg} / \mathrm{dl}$, C-reactive protein $1.64 \mathrm{mg} / \mathrm{dl}$, carcinoembryonic antigen $1.7 \mathrm{ng} / \mathrm{ml}$, and carbohydrate antigen 19-9 (CA19-9) $6.6 \mathrm{U} / \mathrm{ml}$. Contrast-enhanced computed tomography (CT) (fig. 1) showed wall thickening and a tumor in the lumen of the small intestine. Moreover, a small amount of ascites and dilation of the proximal ileum were revealed.

He was diagnosed with small bowel obstruction or intussusception of the ileum due to a tumor and immediately admitted to our hospital. Open laparotomy was performed and normograde intussusception was observed in the ileum and reduced by hand. In addition, a tumor was found in the small intestinal lumen $80 \mathrm{~cm}$ proximal to the ileocecal valve. It had acted as a lead point and hence caused the intussusception. Meckel's diverticulum was not detected, and the tumor and $20 \mathrm{~cm}$ of the adjacent ileum were resected. The patient's postoperative course was uneventful.

The macroscopic findings of the lesion were consistent with a submucosal tumor, i.e., the mass was soft and solid and measured $15 \times 15 \times 15 \mathrm{~mm}$. Microscopic observation using hematoxylin-eosin staining found that the tumor extended from the mucosa to the serosa and identified proliferating ducts without atypia and hypertrophic smooth muscle cell bundles (fig. 2 ). The ducts were lined by a tall columnar epithelium and surrounded by smooth muscle cell bundles. No ectopic pancreatic acini or islet cells were detected. Adenomyoma of the ileum was diagnosed histopathologically. Immunohistochemical examination was also performed. In the duct epithelial cells, cytokeratin 7 (CK 7) (ig. 3) and CA19-9 were strongly expressed, while CK 20 and mucin antigen 2 (MUC 2) were not. 


\section{Discussion}

Generally, adult intussusceptions represent $5 \%$ of all intussusception cases and account for only $1-5 \%$ of obstructions in adults [3]. Almost $90 \%$ of adult intussusceptions are secondary to a pathological condition that serves as a lead point such as carcinoma, polyps, Meckel's diverticulum, colonic diverticulum, strictures, or benign neoplasm [5]. Malignancy is present in approximately $13-47 \%$ of enteric intussusceptions and in $33-62.5 \%$ of colonic intussusceptions [6-8]. Surgical resection without radiological decompression is performed in most adult cases [9]. Adult intussusception requires surgical intervention because of structural anomalies and the high incidence of malignancy. However, the extent of bowel resection required and whether the intussuscepted bowel should be reduced are disputed. Intraluminal seeding and venous embolization of malignant cells during intraoperative manipulation are employed for the primary reduction of intussusceptions in adults, which might permit a more limited resection [7].

Clinically, our case presented with intussusceptions caused by adenomyoma of the ileum. Below, we summarize the characteristics of the 18 previous cases of adenomyoma of the ileum reported in the English language literature (table 1) [3, 10-24]. While 12 cases (63\%) involved patients that were less than 18 years old (children), 7 cases (37\%) involved patients who were 18 years old or older (adults). 11 cases (58\%) presented with symptoms of intussusception, and 9 of these cases involved children. It is known that adenomyoma of the ileum often causes intussusception; however, the intussusception was often asymptomatic in the adult cases, and hence was found incidentally in 4 of 7 incidental cases (57\%), as shown in table 1 . It was concluded that ileal adenomyoma often causes intussusception, especially in children, and a tendency towards the incidental discovery of intussusception was noted in adults.

As shown in table 1, an accurate preoperative diagnosis was only obtained in 6 cases (50\%). The preoperative diagnosis of intussusceptions is difficult, and the frequency of a correct preoperative diagnosis ranged from 40.7 to $50 \%$ in previous studies [4]. Abdominal CT is currently considered to be the most sensitive radiological method for diagnosing intussusception. The characteristic CT features of intussusceptions include a homogenous target or a sausage-shaped soft tissue mass with layering. The diagnostic accuracy of CT ranged from 58 to $100 \%$ in recent reports $[2,4]$.

As mentioned above, the necessity of intraoperative reduction of intussusceptions in adults is disputed. However, especially for enteric intussusception, recent reports have recommended initial reduction of the externally viable bowel prior to resection $[8,9]$. The incidence of malignancy is lower in enteric than in colonic intussusceptions, and metastatic tumors were found in the majority of cases $[2,6-8]$. Thus, reduction of the intussusception followed by resection is considered to be a prudent approach in order to achieve optimal preservation.

Adenomyoma of the gastrointestinal tract is rare, and its pathogenesis has not been fully elucidated. The histopathological findings of adenomyoma are characterized by glandular structures lined by a cuboidal to tall columnar epithelium surrounded by bundles of smooth muscle cells; however, the histogenesis of the condition is disputed. The most widely accepted hypothesis is that these lesions represent a form of myoepithelial hamartoma or a type III pancreatic heterotopia $[1,13,25,26]$. In this study, 
immunohistochemical examination was performed in an attempt to increase our understanding of the pathogenesis of adenomyoma. As a result, we detected the expression of CK 7 and CA19-9 and the absence of CK 20 expression, which are similar to the characteristics of the pancreatic duct epithelium. Judging from these results and the absence of MUC 2 expression, it is suggested that the glandular component of our case was not composed of intestinal epithelial cells, but rather of pancreatic duct epithelial cells. Our case was diagnosed as adenomyoma of the ileum, therefore in our opinion the pathogenesis of this lesion supports the heterotopic pancreas theory.

In summary, clinically, ileal adenomyoma should be considered as a cause of intussusception in adults. It is also suggested that adenomyoma is a form of heterotopic pancreatic tissue.

\section{Disclosure Statement}

The authors declare that they have no conflicts of interest. 


\begin{tabular}{|c|c|c|c|}
\hline $\begin{array}{r}\text { Case Reports in } \\
\text { Gastroenterolooy }\end{array}$ & $\begin{array}{l}\text { Case Rep Gastroenterol 2011;5:602-609 } \\
\text { DOI: 10.1159/000333400 }\end{array}$ & $\begin{array}{l}\text { Published online: } \\
\text { October 7, } 2011\end{array}$ & $\begin{array}{l}\text { @ } 2011 \text { S. Karger AG, Basel } \\
\text { ISSN 1662-0631 } \\
\text { www.karger.com/crg }\end{array}$ \\
\hline
\end{tabular}

Table 1. Cases of ileal adenomyoma reported in the English language literature

\begin{tabular}{|c|c|c|c|c|c|c|c|c|c|}
\hline No. & First author & Year & Age & Sex & $\begin{array}{l}\text { Preoperative } \\
\text { diagnosis }\end{array}$ & $\begin{array}{l}\text { Diagnostic } \\
\text { examination }\end{array}$ & $\begin{array}{l}\text { Intra- } \\
\text { operative } \\
\text { reduction }\end{array}$ & $\begin{array}{l}\text { Intraoperative } \\
\text { conditions }\end{array}$ & Histopathology \\
\hline 1 & Schwartz [10] & 1958 & 8 months & male & ND & ND & $\bigcirc$ & intussusception & $\begin{array}{l}\text { myoepithelial } \\
\text { hamartoma }\end{array}$ \\
\hline 2 & Benisch [11] & 1978 & 47 years & female & uterine fibromyomata & ND & $\mathrm{x}$ & incidental findings & adenomyoma \\
\hline 3 & Rosenmann [12] & 1980 & 2 days & female & rupture of the intestine & $\mathrm{X}$ ray & $\mathrm{x}$ & intestinal atresia & $\begin{array}{l}\text { leiomyomatous } \\
\text { hamartosis }\end{array}$ \\
\hline 4 & Gal [3] & 1986 & 82 years & female & small bowel obstruction & $\mathrm{X}$ ray & ND & intussusception & $\begin{array}{l}\text { adenomyomatous } \\
\text { hamartoma }\end{array}$ \\
\hline 5 & $\operatorname{Kim}[13]$ & 1990 & 7 years & male & small bowel obstruction & $\begin{array}{l}\text { abdominal CT, } \\
\text { ultrasound }\end{array}$ & ND & intussusception & adenomyoma \\
\hline 6 & Gal [14] & 1991 & 9 months & male & small bowel obstruction & ND & $\mathrm{O}$ & intussusception & adenomyoma \\
\hline 7 & Gal [14] & 1991 & 79 years & male & colon carcinoma & ND & $\mathrm{x}$ & incidental findings & adenomyoma \\
\hline 8 & Lamki [15] & 1993 & 1 year & male & intussusception & barium enema & $\mathrm{O}$ & intussusception & $\begin{array}{l}\text { adenomyomatous } \\
\text { hamartoma }\end{array}$ \\
\hline 9 & Serour [16] & 1994 & 3 years & male & $\begin{array}{l}\text { foreign body post } \\
\text { reduction by air enema }\end{array}$ & $\mathrm{X}$ ray & $\mathrm{x}$ & $\begin{array}{l}\text { intestinal intramural } \\
\text { mass }\end{array}$ & adenomyoma \\
\hline 10 & Chan [17] & 1994 & 5 months & female & ND & ND & $\mathrm{O}$ & intussusception & adenomyoma \\
\hline 11 & Chan [17] & 1994 & 3 years & male & ND & ND & $\mathrm{x}$ & incidental findings & adenomyoma \\
\hline 12 & Gonzalvez [18] & 1995 & 2 years & male & intussusception & pneumoenema & $\mathrm{O}$ & intussusception & $\begin{array}{l}\text { myoepithelial } \\
\text { hamartoma }\end{array}$ \\
\hline 13 & Tanaka [19] & 1996 & 24 years & male & submucosal ileal tumor & $\begin{array}{l}\text { small bowel } \\
\text { barium study }\end{array}$ & $\mathrm{x}$ & melena & $\begin{array}{l}\text { myoepithelial } \\
\text { hamartoma }\end{array}$ \\
\hline$\overline{14}$ & Yamagami [20] & 1997 & 4 months & male & intussusception & barium enema & $\mathrm{O}$ & intussusception & $\begin{array}{l}\text { myoepithelial } \\
\text { hamartoma }\end{array}$ \\
\hline 15 & Ueyama [21] & 2001 & 52 years & female & $\begin{array}{l}\text { peritonitis caused by } \\
\text { perforated appendicitis }\end{array}$ & abdominal CT & $\mathrm{x}$ & peritonitis & adenomyoma \\
\hline 16 & Park [22] & 2003 & 7 months & male & intussusception & $\begin{array}{l}\text { abdominal } \\
\text { ultrasound }\end{array}$ & ND & intussusception & adenomyoma \\
\hline$\overline{17}$ & Mouravas [23] & 2003 & 18 months & male & intussusception & $\begin{array}{l}\text { abdominal } \\
\text { ultrasound }\end{array}$ & O & intussusception & adenomyoma \\
\hline 18 & Takahashi [24] & 2006 & 75 years & male & ND & ND & ND & autopsy findings & adenomyoma \\
\hline 19 & present case & 2010 & 68 years & male & small bowel obstruction & abdominal CT & 0 & intussusception & adenomyoma \\
\hline
\end{tabular}

$\mathrm{ND}=$ Not described; $\bigcirc$ = reduction was performed; $\mathrm{x}$ = reduction was not performed. 


\begin{tabular}{r|l|l|l} 
Case Reports in & $\begin{array}{l}\text { Case Rep Gastroenterol 2011;5:602-609 } \\
\text { DOI: 10.1159/000333400 }\end{array}$ & $\begin{array}{l}\text { Published online: } \\
\text { October 7, 2011 }\end{array}$ & $\begin{array}{l}\text { O 2011 S. Karger AG, Basel } \\
\text { ISSN 1662-6031 } \\
\text { www.karger.com/crg }\end{array}$ \\
\hline
\end{tabular}

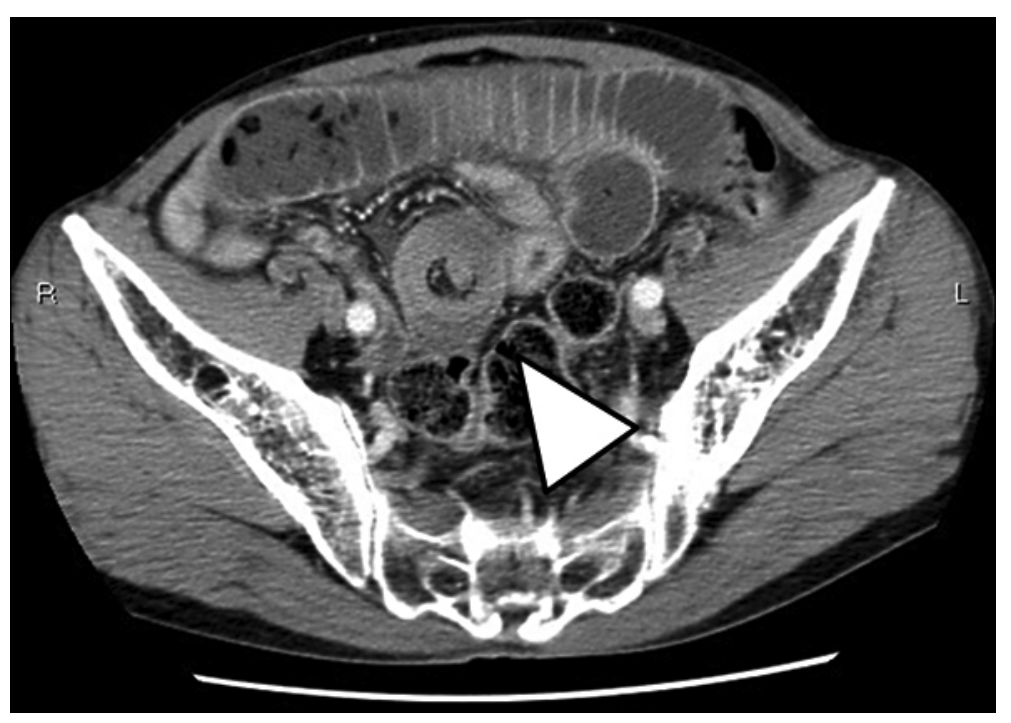

Fig. 1. Enhanced CT of the abdomen and pelvis showed a thickened wall and a tumor-like lesion in the ileum (arrowhead) as well as dilation of the proximal small intestine.

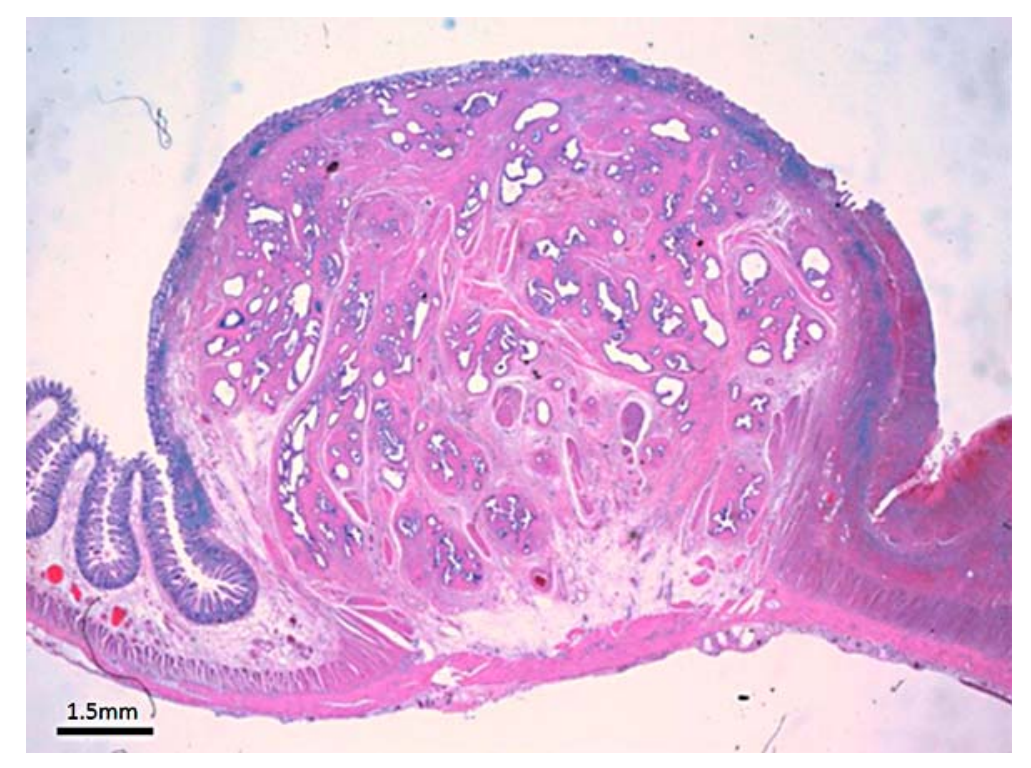

Fig. 2. Loupe image showing proliferating duct cells surrounded by bundles of smooth muscle cells from the submucosa to the serosa (hematoxylin-eosin stain, $\times 4$ ). 


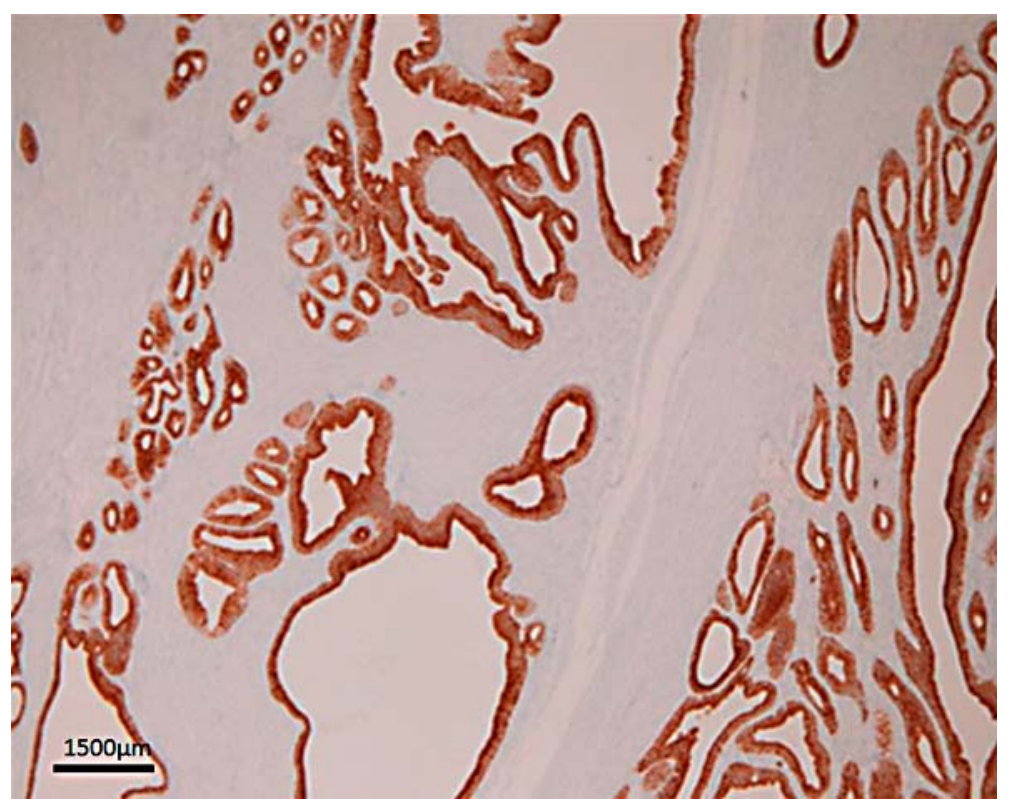

Fig. 3. Immunohistochemical examination revealed strong expression of CK 7 in the proliferating epithelial duct cells (CK 7 stain, $\times 40)$.

\section{References}

$\rightarrow$ Qing X, Petrie BA, Buslon V, French S: Adenomyoma of the jejunum. Exp Mol Pathol 2009;86:127-130.

$\longrightarrow 2$ Azar T, Berger DL: Adult intussusception. Ann Surg 1997;226:134-138.

3 Gal R, Kolkow Z, Nobel M: Adenomyomatous hamartoma of the small intestine: a rare cause of intussusceptions in an adult. Am J Gastroenterol 1986;12:1209-1211.

-4 Wang LT, Wu CC, Yu JC, Hsiao CW, Hsu CC, Jao SW: Clinical entity and treatment strategies for adult intussusceptions: 20 years' experience. Dis Colon Rectum 2007;50:1941-1949.

-5 Marinis A, Yiallourou A, Samanides L, Dafnios N, Anastasopoulos G, Vassiliou I, Theodosopoulos T: Intussusception of the bowel in adults: a review. World J Gastroenterol 2009;15:407-411.

66 Weilbaecher D, Bolin JA, Hearn D, Ogden W: Intussusception in adults. Review of 160 cases. Am J Surg 1971;121:531-535.

7 Nagorney DM, Sarr MG, McIlrath DC: Surgical management of intussusception in the adult. Ann Surg 1981;193:230-236.

-8 Zubaidi A, Al-Saif F, Silverman R: Adult intussusception: a retrospective review. Dis Colon Rectum 2006;49:1546-1551.

\$9 Yalamarthi S, Smith RC: Adult intussusception: case reports and review of literature. Postgrad Med J 2005;81:174-177.

10 Schwartz SI, Radwin HM: Myoepithelial hamartoma of the ileum causing intussusception. AMA Arch Surg 1958;77:102-104.

11 Benisch B, Peison B: Adenoma of the ileum. Am J Obstet Gynecol 1978;131:582-584.

12 Rosenmann E, Maayan C, Lernau O: Leiomyomatous hamartosis with congenital jejunoileal atresia. Isr J Med Sci 1980;16:775-779.

13 Kim CJ, Choe GY, Chi JG: Foregut choristoma of the ileum (adenomyoma) - a case report. Pediatr Pathol 1990;10:799-805.

14 Gal R, Rath-Wolfson L, Ginzburg M, Kessler E: Adenomyomas of the small intestine. Histopathology 1991;18:369-371. 
15 Lamki N, Woo CL, Watson AB Jr, Kim HS: Adenomyomatous hamartoma causing ileoileal intussusception in a young child. Clin Imaging 1993;17:183-185.

16 Serour F, Gorenstein A, Lipnitzky V, Zaidel L: Adenomyoma of the small bowel: a rare cause of intussusceptions in childhood. J Pediatr Gastroenterol Nutr 1994;18:247-249.

17 Chan YF, Roche D: Adenomyoma of the small intestine in children. J Pediatr Surg 1994;29:1611-1612.

18 Gonzalvez J, Marco A, Andujar M, Iniguez L: Myoepithelial hamartoma of the ileum: a rare case of intestinal intussusceptions in children. Eur J Pediatr Surg 1995;5:303-304.

19 Tanaka N, Seya T, Onda M, Kanazawa Y, Naitoh Z, Asano G, Hao K: Myoepithelial hamartoma of the small bowel: report of a case. Surg Today 1996;26:1010-1013.

20 Yamagami T, Tokiwa K, Iwai N: Myoepithelial hamartoma of the ileum causing intussusceptions in an infant. Pediatr Surg Int 1997;12:206-207.

-21 Ueyama N, Kuwashima S, Nakayama A, Nakanishi K, Okuchi K, Kagoshima T, Nakajima Y: Ileal adenomyoma accompanied by primary peritonitis. Surg Today 2001;31:826-829.

22 Park HS, Lee SO, Lee JM, Kang MJ, Lee DG, Chung MJ: Adenomyoma of small intestine: report of two cases and review of the literature. Pathol Int 2003;53:111-114.

-23 Mouravas V, Koutsoumis G, Patoulias J, Kostopoulos I, Kottakidou R, Kallergis K, Kepertis C, Liolios N: Adenomyoma of the small intestine in children: a rare cause of intussusception: a case report. Turk J Pediatr 2003;45:345-347.

24 Takahashi Y, Fukushima J, Fukusato T, Shigeo M: Adenomyoma with goblet and Paneth cells of the ileum. Pathol Res Pract 2006;202:549-553.

25 Lee JS, Kim HS, Jung JJ, Kim YB: Adenomyoma of the small intestine in an adult: a rare cause of intussusceptions. J Gastroenterol 2002;37:556-559.

26 Dawson I: Hamartoma in the alimentary tract. Gut 1969;10:691-694. 